\author{
I.L. Hrabchuk, PhD in Economics, Associate Professor \\ Zhytomyr State Technological University
}

\title{
Issues of Social Policy Implementation for ATO (OUF) Fallen Servicemen's Family Members under Conditions of Hybrid War ${ }^{1}$
}

The article determines the main issues of the social policy implementation for the members of families of the servicemen fallen in the area of the ATO and shows the ways of their solution as a precondition for the social tension reduction under conditions of the hybrid war.

Analyzing and systematizing the works of scientists, and taking into account the existing practice, the author systematizes the principal issues of the social policy realization for the members of families of the servicemen fallen (died) in the area of the ATO.

The relatives of the fallens in the area of the ATO have not only to cope with their sorrow, think about further material security, but also solve the problem about obtaining the status of the fallen serviceman's family member. The paper reveals the procedure of obtaining the status of the ATO fallen serviceman's family member by individuals and this will allow to provide the latter ones with the proper level of social security and guarantees. The author also determines the ways of increasing the efficiency of the existing system of privileges and compensations for the family members of the fallen servicemen, and proposes to implement the electronic registration of the privileges and compensations for the participants of the ATO and members of their families as well.

Keywords: social policy; social tension; hybrid war; anti-terrorist operation; status of the fallen's family member.

Settlement of the problem. On the 30-th of April 2018 Ukraine officially started the Operation of United Forces (OUF) after the anti-terrorist operation (ATO). Official explanations indicate that this will not influence upon the privileges got by ATO participants. In addition, according to the introduced changes, the individuals who will take part in the OUF will have a right for the status of a participant of military operations. We consider the changes will concern the family members of the servicemen fallen in the area of the OUF. However, at present, the indicated changes have not been introduced, and the existing mechanism of obtaining this status by the families of the ATO area servicemen is not worked out in detail on a legislative level and cause a lot of debates. All this shows that the implementation of the social policy simply cannot take place on the necessary level for this category of population.

According to the data gathered on the 1-st of September 2016 the status of the fallen's family member was given to over 6100 family members of the fallen ATO participants [9], and unfortunately, this index is constantly growing. The relatives of the fallens have not only to cope with their sorrow, think about further material security (because sometimes the servicemen of the ATO area were the only supporters for their families), but also solve the problem about obtaining the status of the fallen serviceman's family member. The data concerning the military losses of Armed Forces of Ukraine during the ATO (the data of the 2-nd March 2018 shows that 2378 servicemen died during this period [3]) confirms the significance of solving the current problem for the fallens' relatives.

Thus, scientists, determining the first steps in the reformation of the social sphere, alongside with the necessity to implement an accumulating pension scheme, to create the market of social services, to start the Unified data base for the sphere of social security, indicate on the importance of creation of the real plan of measures to solve the problems of the ATO participants, «...the subsoil for its development will become the developed state complex strategy concerning the realization of the state policy to overcome the consequences of the Russian aggression in Ukraine and prevent from further social crises» [8, p. 48]. In spite of the mentioned data, the social policy in our country, even taking into consideration the armed conflict in the East of Ukraine, remains on the secondary positions provoking in this way the intensification of social tension.

Analysis of the recent researches and publications. Some aspects of the social policy for the ATO participants are often studied in the works of researchers. Such scientists as L.Voropai [1], O.Korolchuk [5], M.Kravchenko [6], L.Kysil [4], B.Matsko [7], and M.Onufryk [8] examine the issue of providing social and economic assistance to the servicemen who are in the areas of armed conflicts. However, in spite of the significant results of the scientists on the researched topic, the issue of social security for the family members of the fallens in the ATO area still remains undisclosed.

Purpose of the article The study aims at determining the principal problems of the social policy implementation for the family members of the servicemen fallen in the OUF area (ATO), outlining the ways of their solution as the preconditions for reduction of the social tension during the hybrid war.

${ }^{1}$ The work is carried out according to RSW № 48 «Transformation of Social Responsibility of Business under Conditions of Hybrid War» 
Research results. During the recent years, definite steps have been taken to improve the social security of the participants of battle actions, including their family members, in particular:

- the amounts of payments to the family members of the servicemen fallen in the ATO area were increased;

- the mechanism for providing the families of the fallen servicemen with accommodation and this ensures incoming of means to get accommodation directly to citizens;

- the Unified list of the ATO participants was created and it was planned to be expanded with the data about the individuals with disability because of the war, the family members of fallen war participants.

However, the analysis of the current state of the social policy realization for the family members of the servicemen fallen (died) in the ATO area revealed the existence of the following main problems:

- the imperfection of the current legislation about providing the status of the ATO fallen (died) serviceman's family member;

- low efficiency of the existing system of privileges and compensations for the family members of the fallen servicemen;

- the lack of strict control over the implementation of social privileges.

The urgent issues, which cause the growth of social tension among the ATO participants and family members of the fallen servicemen, called forth by the obstacles with which they are faced with in the process of obtaining the privileges envisaged by the current legislation. Such obstacles are often artificial, however, in many cases they are connected with the imperfection of the current legislation. The principal issues of the normative nature are caused by the absence of the sufficient experience in the creation of legislative acts in the present sphere. The facts that Ukraine was not ready to conduct the war, to work out the mechanism of providing the ATO participants and members of their families with material, social, and psychological assistance appeared also to be significant reasons.

At present the matter of obtaining the status of an ATO fallen (died) serviceman's family member by a certain category of individuals is regulated with the principal normative and legal act, which is The Law of Ukraine «About the Status of Disabled Soldiers, and Guarantees of their Social Security» [2]. In addition, the Decree of the Cabinet of Ministers of Ukraine «About approval of the Order of obtaining the status for an individual who is included in the Law of Ukraine "About the Status of Disabled Soldiers, and Guarantees of their Social Security» to some categories of individuals of 23 September 2015, № 740 [10], is valid, and this decree actually approved the procedure of obtaining the status for an individual who is included in the Law of Ukraine «About the Status of Disabled Soldiers, and Guarantees of their Social Security» to certain categories of individuals including the family members of the servicemen fallen in the ATO area.

The procedure of providing the status of the fallen serviceman's family member includes gathering the increased list of documents, and this requires much time and efforts, but the result is unknown as there is no unified approach among social authorities to the present issue. And judicial case 806/1456/17 that was examined by Zhytomyr District Administrative Court can be an excellent example of this. It says that in March 2017 a woman applied to the Department of Labour and Social Security of Population (DLSSP) of Bohunskii Regional Council of the city Zhytomyr and Zhytomyr United Urban Military Commissariat of Zhytomyr oblast with the written request and corresponding documents to get both the status of «Fallen (Died) Disabled Soldier's Family Member» and the necessary card. She explained that she was not an official wife to the fallen, and the court confirmed the fact of her living together with the fallen like a family by its decision. DLSSP of Bohunskii Regional Council of the city Zhytomyr refused the woman in her obtaining the status of the individual who is included in the Law of Ukraine «About the Status of Disabled Soldiers, and Guarantees of their Social Security» because the latter one was not an official wife of the fallen.

Zhytomyr United Urban Military Commissariat of Zhytomyr oblast refused the prosecutor to accept the documents for examination because of the deficiency of their presentation and indicated about the absence of marriage certificate, in particular. Thus, the individual had to apply to the court for protection of her infringed rights. Zhytomyr District Administrative Court took into account the fact of illegality for the actions of DLSSP of Bohunskii Regional Council of the city Zhytomyr and Zhytomyr United Urban Military Commissariat of Zhytomyr oblast and obliged these authorities to study again the individual's application about providing her the status and giving out the card of «Family Member of the Fallen (Died)» and hand the card with the inscription «Card of Fallen's Family Member».

The present case illustrates inefficiency of the existing mechanism for receiving the status of the family member fallen in the ATO area. After the death of the relative, the person has not only to gather and present all the documents to different authorities independently, but also to protect their infringed rights in the judicial authorities. Thus, we consider that it is necessary to set the obligation about gathering the documents (death certificate or the notification about person's death; the resolution of forensic medical analysis (staff military medical commission) (if there is a possibility to make it); the record of service investigation; the papers about the fallen serviceman's direct participation in the ATO) to the commander of the army unit, where the died, fallen (missing) was on the service. This, in its turn, will allow to provide the necessary level of the social security and guarantees for such individuals. For this purpose it will be reasonable to supplement the Law of Ukraine «About 
the Status of Disabled Soldiers, and Guarantees of their Social Security» with the above-mentioned additional regulation. The procedure itself and the algorithm of actions will be reasonable to detail in the new version of The Order for providing the status of an individual included in the Law of Ukraine «About the Status of Disabled Soldiers, and Guarantees of their Social Security», to some categories of persons.

In conclusion to the above-mentioned facts, we consider that it is reasonable to fulfil the following procedure of obtaining the status of ATO fallen serviceman's family member by an individual on the legislative level (Fig.1.). The proposed mechanism will provide the double-sided control in making a final decision about providing the status of fallen's family member to a person, namely, by regional military commissariats and the State department of Ukraine for matters of war veterans and ATO participants.

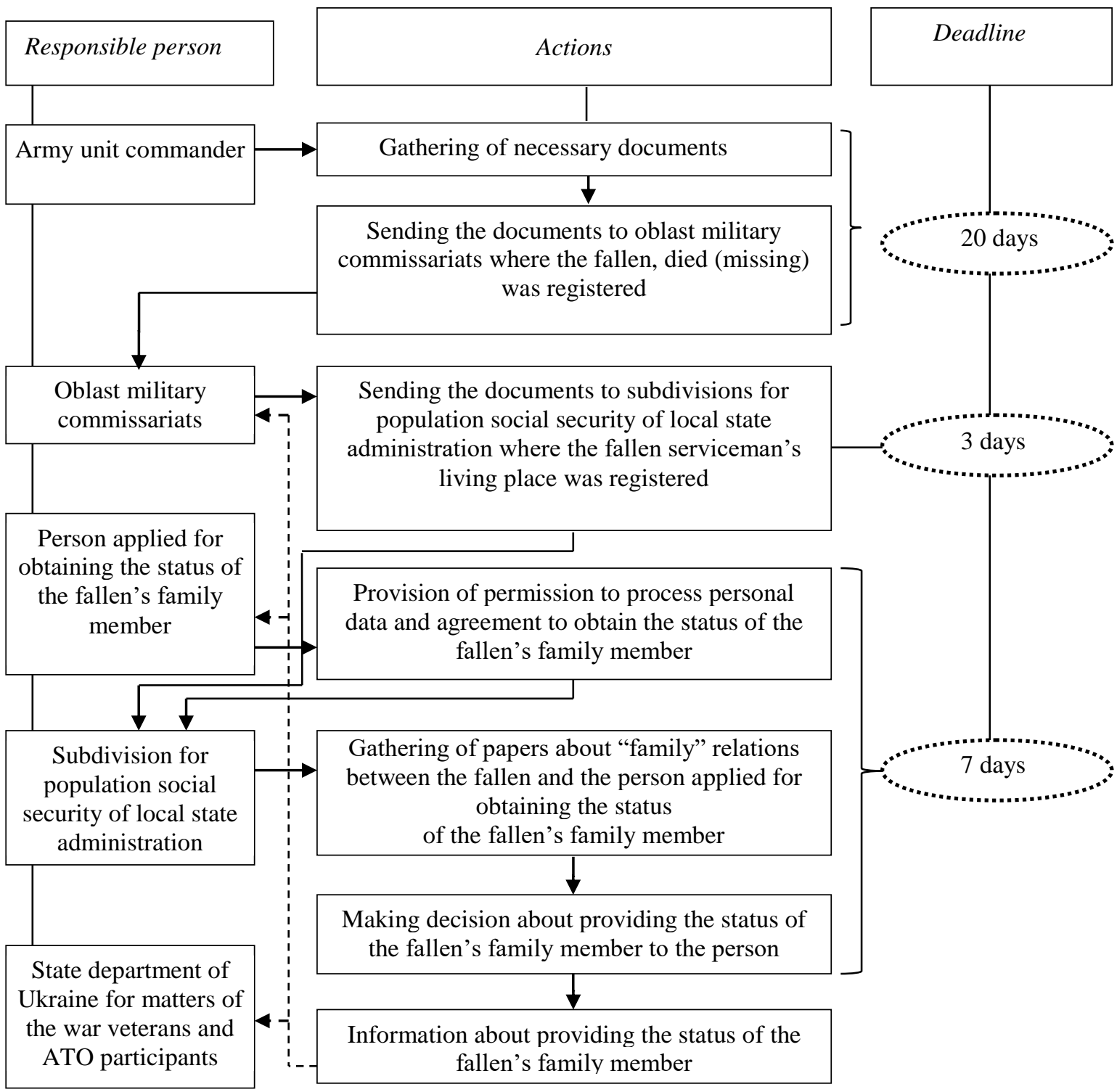

Fig. 1. Proposed mechanism for providing the status of the ATO fallen serviceman's family member

In accordance with the mechanism proposed, the participation of the ATO fallen serviceman's family members is minimal. As soon as the persons get the status of fallen family member (approximately in a month), such individuals will have the privileges provided by article 15 of the Law of Ukraine «About the Status of Disabled Soldiers, and Guarantees of their Social Security», in particular:

- free receiving of medicines and medical means; discounts in payments for accommodation;

- $\quad$ providing with a regular annual leave when it is comfortable for them;

- $\quad$ payment of taxes, duties and other budgetary payments according to tax and customs legislations, etc. 
The social security of the ATO fallen servicemen's children also needs some attention. In spite of that, on the 27-th of February 2018 the Law of Ukraine № 2300-VIII «About changes to some laws of Ukraine concerning the state support of participants of battle operations, people with the disability caused by the war and their children for getting technical and higher education» was adopted, it comes into operation only on the 1 of January 2019, that is why, it does not involve the entrance campaign of 2018.

The state program for providing the state purpose-oriented support to some categories of citizens to get technical and higher education, also to the ATO fallen servicemen's children, is in function in Ukraine. However, to obtain the purpose-oriented support for education and to use entrance quotas, a university applicant himself must bring a written request and the necessary documents to the educational institution. And such support is provided according to the decision made by the head of the educational institution; so, it confirms the fact that not all the children will be able to use their rights. The above-mentioned information is the evidence of the lack of strict mechanism for privileged entrance the fallen servicemen's children to educational institutions.

The next issue of the social policy implementation for the ATO fallen servicemen's family members is providing them with psychological aid. It goes without saying that such aid is very necessary for demobilized ATO participants, but the issue of providing the members of their families with social and psychological rehabilitation services are not actually arisen. On the other hand, providing the present category of population with such qualified aid would allow to detect stressful disorders in proper time and minimize their consequences.

Taking into account all mentioned above, we consider the scientists' propositions concerning the necessity of the electronic registration of the privileges and compensations to be logical $[6$, p. $41 ; 8$, p. 48]; such a registration under conditions of the Unified list of the ATO participants introduction, will allow to reveal no purpose-oriented use of costs, to prevent misuse, and in this way will give a possibility to direct them for privileges for the ATO participants, and the members of their families. Besides, it will provide the necessary preconditions for long-term planning of social expenses and financing the privileges and compensations in accordance with the present direction.

Conclusions. In order to avoid the growth of social tension among population it is proposed a number of measures for solving the problems of the social policy concerning the ATO fallen servicemen's family members. The analyzed practice shows the insufficient level of developed mechanism for obtaining the status of the ATO fallen serviceman's family member. The article proposes the list and the order of presenting papers for getting the status of the family member of the died, fallen (missing) when the latter ones participated in the ATO. To increase the efficiency of the existing system of privileges and compensations for the fallen servicemen's family members it is proposed to fulfil the strict order of out-of-competitive entrance into educational institutions for the fallen servicemen's children, and provide them with psychological aid on the local level. To increase the control over the implementation of social privileges, and for the fallen servicemen's family members in particular, the author substantiates the expedience for the implementation of the electronic registration of the privileges and compensations.

\section{References:}

1. Воропай Л.А. Соціальний захист учасників АТО як складова державної соціальної політики / Л.А. Воропай URL : http://www.kbuapa.kharkov.ua/e-book/conf/2016-5/doc/4/27.pdf.

2. «Про статус ветеранів війни, гарантії їх соціального захисту» : закон України : № 3552-XII : станом на 22.10.93 / Верховна Рада України. URL : http://zakon5.rada.gov.ua/laws/show/3551-12.

3. Із початку АTO на Донбасі загинуло 2 тис. 382 українських військових - Генштаб. URL : http://gordonua.com/ukr/news/war/z-pochatku-ato-na-donbasi-zaginuli-2-tis-382-ukrajinskih-vijskovih-genshtab234484.html.

4. Кисіль Л.С. Правове регулювання діяльності органів публічної адміністрації щодо реалізації і захисту прав учасників АТО / Л.С. Кисіль // Правова держава. - 2017. - Вип. 28. - С. 314-324.

5. Корольчук О.Л. Актуальність вивчення питань щодо державного управління медико-соціальним забезпеченням учасників АТО та членів їх сімей / О.Л. Корольчук // Інвестиції: практика та досвід. - 2016. № 15. - C. 47-51.

6. Кравченко М.В. Основні проблеми соціального захисту учасників АТО / М.В. Кравченко // Аспекти публічного управління. - 2015. - № 11-12. - С. 36-43.

7. Мацько B.A. Особливості адміністративно-правового механізму забезпечення житлом учасників АТО / B.А. Мацько // Наука і правоохорона. - 2015. - № 4. - С. 64-69.

8. Онуфрик М. Соціальна політика в Україні впродовж 25 років: стан, виклики і перспективи / М.Онуфрик // АГОРА. - 2016. - Вип. 17. - С. 41-48.

9. Про Рекомендації парламентських слухань на тему : «Державні гарантії соціального захисту учасників антитерористичної операції, Революції Гідності та членів їхніх родин: стан і перспективи» : постанова Верховної Ради України : № 1843-VIII : станом на 09.02.17 / Верховна Рада України. URL : http://zakon3.rada.gov.ua/laws/show/1843-19.

10. Про затвердження Порядку надання статусу особи, на яку поширюється чинність Закону України «Про статус ветеранів війни, гарантії їх соціального захисту» деяким категоріям осіб» : постанова Кабінету 
Міністрів України : № 740 : станом на 23.09.15 / Кабінет Міністрів України. URL : https://www.kmu.gov.ua/ua/npas/248515121.

\section{References:}

1. Voropaj, L.A. (2016), Social'nyj zahyst uchasnykiv ATO jak skladova derzhavnoi' social'noi' polityky, [Online], available at: www.kbuapa.kharkov.ua/e-book/conf/2016-5/doc/4/27.pdf

2. Verhovna Rada Ukrai'ny (1993), «Pro status veteraniv vijny, garantii' i'h social'nogo zahystu», zakon Ukrai'ny, N 3552-XII, stanom na 22 zhovtnja, [Online], available at: http://zakon5.rada.gov.ua/laws/show/3551-12

3. «Iz pochatku ATO na Donbasi zagynulo 2 tys. 382 ukrai'ns'kyh vijs'kovyh - Genshtab», [Online], available at: http://gordonua.com/ukr/news/war/z-pochatku-ato-na-donbasi-zaginuli-2-tis-382-ukrajinskih-vijskovih-genshtab234484.html

4. Kysil', L.Je. (2017), «Pravove reguljuvannja dijal'nosti organiv publichnoi' administracii' shhodo realizacii' i zahystu prav uchasnykiv ATO», Pravova derzhava, Vol. 28, pp. 314-324.

5. Korol'chuk, O.L. (2016), «Aktual'nist' vyvchennja pytan' shhodo derzhavnogo upravlinnja medyko-social'nym zabezpechennjam uchasnykiv ATO ta chleniv i'h simej», Investycii': praktyka ta dosvid, No. 15, pp. 47-51.

6. Kravchenko, M.V. (2015), «Osnovni problemy social'nogo zahystu uchasnykiv ATO», Aspekty publichnogo upravlinnja, No. 11-12, pp. 36-43.

7. Mac'ko, V.A. (2015), «Osoblyvosti administratyvno-pravovogo mehanizmu zabezpechennja zhytlom uchasnykiv ATO», Nauka i pravoohorona, No. 4, pp. 64-69.

8. Onufryk, M. (2016), «Social'na polityka v Ukrai'ni vprodovzh 25 rokiv: stan, vyklyky i perspektyvy», AGORA, Vol. 17, pp. 41-48.

9. Verhovna Rada Ukrai'ny (2017), «Pro Rekomendacii' parlaments'kyh sluhan' «Derzhavni garantii' social'nogo zahystu uchasnykiv antyterorystychnoi' operacii', Revoljucii' Gidnosti ta chleniv i'hnih rodyn: stan i perspektyvy», postanova, N 1843-VIII, stanom na 09 ljutogo, [Online], available at: http://zakon3.rada.gov.ua/laws/show/1843-19

10. Kabinet Ministriv Ukrai'ny (2015), «Pro zatverdzhennja Porjadku nadannja statusu osoby, na jaku poshyrjujet'sja chynnist' Zakonu Ukrai'ny «Pro status veteraniv vijny, garantii' i'h social'nogo zahystu» dejakym kategorijam osib», postanova, N 740, stanom na 23 veresnja, [Online], available at: https://www.kmu.gov.ua/ua/npas/248515121

Грабчук Ірина Леонідівна ? кандидат економічних наук, доцент кафедри обліку i аудиту Житомирського державного технологічного університету.

Наукові інтереси:

- комп'ютеризація бухгалтерського обліку;

- проблеми організації бухгалтерського обліку. 